\title{
SURVEI SARANA DAN PRASARANA PEMBELAJARAN PENDIDIKAN JASMANI OLAHRAGA DAN KESEHATAN PADA SEKOLAH MENENGAH PERTAMA DI KABUPATEN PRINGSEWU TAHUN 2019
}

\author{
Nur Afifah Sudibyo ${ }^{1}$, Reza Adhi Nugroho ${ }^{2}$ \\ Universitas Teknokrat Indonesia, ${ }^{\mathbf{1 , 2}}$ \\ nurafifahsudibyo1@ gmail.com ${ }^{1}$ \\ reza.adhi.nugroho@teknokrat.ac.id ${ }^{2}$
}

Abstract

The purpose of this study is to determine the condition of learning facilities and infrastructure of Physical and Sports Physical Education in junior high schools in Pringsewu, 2019. The method of the research used by the writer is qualitative methods, because it describes the availability of learning facilities and infrastructure of Physical and Sports Physical Education through the number of facilities and infrastructure that is available and is needed in learning. Data collection is done by using documentation, observation, and questionnaires. The research instrument that is provided in the form of a questionnaire is the availability of sports facilities and infrastructure. According to the result of the research conducted in State Junior High School, Pringsewu has been able innovating in creating sport modification tools. The modifications made even more widely used for learning in the athletics branch by utilizing simple materials. Each teacher is guided to provide an innovation and modification of the tools for the achievement of the learning process.
\end{abstract}

Keywords: Facilities, Infrastructure, Learning, Physical education, sports and health, Junior High School

\begin{abstract}
Abstrak
Tujuan penelitian ini adalah untuk mengetahui keadaan sarana dan prasarana pembelajaran Pendidikan Jasmani Olahraga dan Kesehatan di SMP di Kabupaten Pringsewu tahun 2019. Metode Penelitian menggunakan metode kualitatif, karena mendeskripsikan ketersediaan sarana dan prasarana pembelajaran Pendidikan Jasmani Olahraga dan Kesehatan melalui jumlah sarana dan prasarana yang adadengan kebutuhan dalam pembelajaran. Pengumpulan data dilakukan dengan menggunakan dokumentasi, observasi, dan angket. Instrumen penelitiannya berupa angket ketersediaan sarana dan prasarana olahraga. Analisis data dalam penelitian ini yakni data kuantitatif, yaitu jumlah sarana dan prasarana olahraga dan kualitatif, berupa temuan modifikasi sarana dan prasarana olahraga. Dari hasil penelitian terhadap ketiga SMP di Kabupaten Pringsewu menunjukan keadaan sarana dan prasarana olahraga cukup ideal untuk menunjang pembelajaran pendidikan jasmani olahraga dan kesehatan. Banyak Guru olahraga SMP di Kabupaten Pringsewu sudah mampu berinovasi dalam menciptakan alat-alat modifikasi olahraga. Alat modifikasi yang dibuatpun lebih banyak digunakan untuk pembelajaran pada cabang atletik dengan memanfaatkan bahan-bahan sederhana setiap guru dituntun memberikan sebuah inovasi dan modifikasi alat guna tercapainya proses pembelajaran.
\end{abstract}

Kata Kunci: Sarana, Prasarana, Pembelajaran, Pendidikan jasmani olahraga dan kesehatan, Sekolah Menengah Pertama

\section{To cite this article:}

Sudibyo, Nur Afifah dan Nugroho, Reza Adhi. (2020). Survei Sarana Dan Prasarana Pembelajaran Pendidikan Jasmani Olahraga Dan Kesehatan Pada Sekolah Menengah Pertama Di Kabupaten Pringsewu Tahun 2019. Journal Of Physical Education, 1 (1), 18-24.

\section{PENDAHULUAN}

Pendidikan Jasmani Olahraga dan Kesehatan merupakan keseluruhan dalam sistem pendidikan secara menyeluruh berkaitan dengan kebugaran dan kesehatan tubuh, Pendidikan Jasmani Olahraga dan Kesehatan 
memliki sebuah tujuan dalam tumbuh kembangnya tingkat kebugaran jasmani manusia yang berhubungan dengan keterampilan gerak, berfikir kritis, keteremapilan aspek sosial, penalaran, stabilitas emosi, sikap moral, dalam perlakuan hidup sehat, pemahaman sebuah lingkungan bersih dalam aspek aktivitas jasmani. Menurut Suherman (2000) menyatakan Pendidikan jasmani dan kesehatan merupakan aspek penting dalam menguasai keterampilan fisik dan keterampilan cabag olahraga. Aspek mulitlateral gerak dalam aspek olahraga menjadi sebuah point penting dalam pembangunan nilai pendidikab olahraga dan kesehatan. Olahraga merupakan bagian dari kehidupan serta salah satu dari kebutuhan jasmani yang penting bagi manusia. Olahraga merupakan bentuk perilaku gerak manusia yang dilakukan secara spesifik cabang olahraganya yang memiliki arah dan tujuan beragam sehingga olahraga merupakan fenomena yang relevan dengan kehidupan sosial untuk tiap orang (Mahfud, 2020).

Pendidikan Jasmani merupakan pelajaran pokok disekolah sebgai alat serta media untuk menuntun perkembangan motorik, keterampilan gerak dasar fisik, pengetahuan bidang penalaran, mengahati sikap emosional, memfasilitiasi siswa menguasai bagaimana manusia bergerak dan melakukan gerak secara efektif dan aman, sehingga mengusai manfaat aktifitas jasmani bagi peningkatan kualitas hidup dan kebiasaan pola dalam hidup bugar yang berorietasi dalam pertumbuhan dan perkembangan seimbang (Yuliandra dan Fahrizqi , 2018). Perkembangan zaman saat ini mengendepankan tingkat kebugaran menjadi aspek penting dalam kurikulum pendidikan olahraga, bagaiamana dalam pendidikan olahreaga mengusai nomor atletik, senam, beladiri dan olahraga permainan yang berorientasi dalam peningkatan kebugaran guna mendukung aspek kognitif dalam perkembangan aspek pendidikan olahraga. Proses belajar mengajar Pendidikan Jasmani dan Kesehatan bagian menyeluruh membutuhkan kelengkapan sarana dan prasrana demi meningkatkankannya sebuah capaian proses pembelajaran. Aktivitas cabang permaianan dalam olahraga disekolah yang diberikan oleh guru pendidikan jasmani akan membantu perkembangan anak secara baik. Kegiatan olahraga permainan memberikan dampak yang sangat baik, salah catu cabang olahraga yang sangat berkembang merupakan sepak bola yang memilki arti jenis permainan yang populer didunia, Indonesia bagian dari perkembangannya (Gumantan dan Mahfud, 2018). Sepak bola menjadi sebuah olahraga permainan yang membutuhkan prasarana yang besar untuk itu cabang olahraga ini menjadi olahraga yang pokok dalam membutuhkan prasarana. Menurut Mahfud ( 2020) menyatakan Sepakbola merupakan permainan beregu yang paling popular di dunia dan bahkan telah menjadi permainan nasional bagi setiap Negara di Dunia. Sepakbola mempunyai daya tarik sendiri dibandingkan dengan olahraga lainnya. Daya tarik sepakbola adalah keterampilan memperagakan kemampuan mengolah bola, penampilan dengan penuh perjuangan, gerakan yang dinamis, disertai dengan kejutan taktik yang membuat penonton kagum melihanya.

Kondisi ruang berlajar dan sekolah sebagian besar memiliki sarana dan prasarana yang cukup memenuhi kriteria layak dalam cabang olahraga yang berhubungan dengan materi pembelajaran pendidikan jasmani. Sebagian besar runag belajar dalam sekolah yang berdomisili kota besar, yang memiliki halaman yang tidak cukup banyak dan luas yang merupakan syarat mutlak dalam prasarana olahraga. Pendidikan jasmani hendaknya menumbuhkan proeses belajar dengan memodifikasi ukuran lapangan, peralatan serta mekanismen bentuk peraturan yang disesuaikan kondisi sekolah (Soepartono, 2000). Guru pendidikan olahraga yang baik hendaknya dapat menyesuaikan kondisi sekolah dalam memodifikasi sarana prasarana apabila sekolah tidak cukup lengkap sebuah peralatan pembelajaran sehingga capaian proses belajar tidak menyimpang dengan kurikulum yang telah dibuat oleh seorang guru, memiliki kreatifitas yang baik dalam mengedepankan variasi dan modifikasi alat menjadi hal yang sangat wajib. Alat oalharaga dipergunakan dalam jangka waktu pendek adalah bola, raket tenis, jaring gawang, stik kasti dan sebagainya (Wirjasantoro, 2005).

Prasarana olaharaga yang dimaksud dalam pendidikan jasmani dan kesehatan adalah fasilitas yang bersifat permanen. Keberlangsungan proses belajar pendidikan jasmani tidak mungkin terlepas dari ketersediaan prasarana yang sangat baik dan layak. Prasarana yang sangat bagus dan baik akan membantu secara baik proses pembelajaran. Prasarana pembelajaran jasmani adalah penunjang terlaksananya proses belajar yang baik yang mempermudah proses belajar dengan memilki tolak ukur yang baik (Soepartono, 2000). Fasilitas yang disebut dengn prasarana olahraga meliputi gedung olahraga, lapangan sepak bola, hall indoor senam yang menunjang proses belajar. Selain memiliki sebuah fasilitas prasarana yang baik point penting adalah dalam perawatan fasilitas olahraga yang dimiliki . Tujuan pemeliharan proses kegiatan belajar menentukan alat dalam kondisi yang baik dan aman yang membantu proses belajar berjalan lancar (Hisyam, 2007).

Fasilitas yang baik serta kelengkapam sarana dan prasarana pendidikan jasmani dan kesehtan harus dimiliki sebuah sekolah,guna tercapainya proses belajar mengajar yamg baik. Pemberian sebuah materi tidak tergaggu sehingga proses belajar mengajar akan berjalan efektif dan efesien. Guru akan lebih mudah dalam proses pembelajaran terlebih dalam aspek penilaian akhir hingga dalam tahapan proses evaluasi belajar mengajar. Berdasarkan kajian yang mendalam peneliti akan menganalisis fasilitas sarana dan prasrana Sekolah 
Menengah Pertama yang ada di Kabupaten Pringsewu tahun 2019. Peneliti merasa tertarik membahas tentang sarana dan prasarana yang ada dan bagaimana fenomena yang muncul apabila sekolah tidak memiliki sarana dan prasarana yang baik dalam penunjang proses pembelajaran disekolah yang ada di Kabupaten Pringsewu.

\section{METODE}

\section{Sampel dan Waktu}

Sampel Penelitian SMP A, SMP B dan SMP C. Waktu penelitian Mei sd Juni 2019

\section{Teknik Pengumpulan Data}

Penelitian menggunakan penelitian kualitatif yang menggambarkan kondisi lapangan dengan observasi secara langsung.

\section{Metode Analisis}

Penelitian pengujian dengan mengunakan validitas isi dengan perbandingan antara isi instrumen denga perencanaan yang ditetapkan terhadap sarana dan prasaran olahraga dan fasilitas kesehatan.

\section{HASIL DAN PEMBAHASAN}

Kabupaten Pringsewu merupakan kabupaten pemekaran dari kabupaten Tanggamus yang letaknya berbatasan antara Pesawaran dan Tanggamus, dan Kabupaten Pringsewu menjadi kabupaten yang sangat strategis. SMP A, SMP B dan SMP C letaknya ditengah kabupaten sehingga pengembangan pembangunan akan mungkin terjadi. Dalam hal penelitian ini melihat hasil sebagai berikut:

\section{Kondisi Sarana Dan Prasarana Pembelajaran dan Ruang UKS SMP A}

Berdasarkan dari analisis dan obersrvasi secara langsung data ketersediaan sarana dan prasarana pembelajaran Pendidikan Jasmani Olahraga dan Kesehatan pada SMP A diperoleh hasil sebagai berikut.

Tabel 1. Sarana dan Prasarana Pembelajaran Pendidikan Jasmani, Olahraga, dan Kesehatan Cabang Permainan SMP A

\begin{tabular}{|c|c|c|c|c|}
\hline No & Cabang & $\begin{array}{l}\text { Sarana dan } \\
\text { Prasarana }\end{array}$ & Jumlah & Persentase \\
\hline \multirow[t]{5}{*}{1} & \multirow[t]{5}{*}{ Bola Voli } & Lapangan & 1 & $100 \%$ \\
\hline & & Tiang & 2 & $100 \%$ \\
\hline & & Net & 1 & $100 \%$ \\
\hline & & Bola & 8 & $73 \%$ \\
\hline & & Peluit & 0 & $0 \%$ \\
\hline \multirow[t]{4}{*}{2} & \multirow[t]{4}{*}{ Bola Basket } & Lapangan & 1 & $100 \%$ \\
\hline & & Tiang Ring & 2 & $100 \%$ \\
\hline & & Bola Basket & 10 & $91 \%$ \\
\hline & & Peluit & 2 & $100 \%$ \\
\hline \multirow[t]{4}{*}{3} & \multirow[t]{4}{*}{ Sepak Bola } & Lapangan & 0 & $0 \%$ \\
\hline & & Bola & 8 & $73 \%$ \\
\hline & & Tiang Gawang & 0 & $0 \%$ \\
\hline & & Peluit & 0 & $0 \%$ \\
\hline
\end{tabular}

Memberikan hasil bahwa sarana dan prasarana cabang permainan di SMP A . (1) lapangan voli dengan secara rinci seperti tabel diatas mendapatkan 100\% masuk dalam kriteria sangat ideal. (2) Bola basket $91 \%$ kategori sangat ideal. (3) Bola Voli dan bola sepakbola 73\% masuk dalam kretaria ideal. (4) Peluit, lapangan sepak bola, gawang memilki persentasi $0 \%$ kategori kurang ideal. 
Tabel 2. Sarana dan Prasarana Kesehatan SMP A

\begin{tabular}{clll}
\hline No & Sarana dan Prasarana & Jumlah & Persentase \\
\hline $\mathbf{1}$ & Ruang UKS & 1 & $100 \%$ \\
\hline $\mathbf{2}$ & Dipan Pemeriksaan & 2 & $100 \%$ \\
\hline $\mathbf{3}$ & Lemari/kotak obat & 1 & $100 \%$ \\
\hline $\mathbf{4}$ & Timbangan & 1 & $100 \%$ \\
\hline $\mathbf{5}$ & Pengukur tinggi badan & 1 & $100 \%$ \\
\hline $\mathbf{6}$ & Tensimeter & 2 & $100 \%$ \\
\hline $\mathbf{7}$ & Termometer & 3 & $100 \%$ \\
\hline $\mathbf{8}$ & Tempat sampah & 1 & $100 \%$ \\
\hline $\mathbf{9}$ & Alat P3K (obat-obatan) & 1 set & $100 \%$ \\
\hline $\mathbf{1 0}$ & Tandu & 2 & $100 \%$ \\
\hline
\end{tabular}

Dalam tabel diata menjelaskan bahawa fasilitas yang dimilki oleh SMP A kategori sangat ideal dibuktikan dengan persentase $100 \%$ alat yang ada.

2. Kondisi sarana dan prasarana Pembelajaran dan Ruang UKS SMP B

Tabel 3. Sarana dan Prasarana Pembelajaran Pendidikan Jasmani, Olahraga, dan Kesehatan, Cabang Permainan SMP B

\begin{tabular}{|c|c|c|c|c|}
\hline No & Cabang & $\begin{array}{l}\text { Sarana dan } \\
\text { Prasarana }\end{array}$ & Jumlah & Persentase \\
\hline \multirow[t]{5}{*}{1} & \multirow[t]{5}{*}{ Bola Voli } & Lapangan & 1 & $100 \%$ \\
\hline & & Tiang & 2 & $100 \%$ \\
\hline & & Net & 9 & $100 \%$ \\
\hline & & Bola & 6 & $55 \%$ \\
\hline & & Peluit & 0 & $0 \%$ \\
\hline \multirow[t]{4}{*}{2} & \multirow{4}{*}{ Bola Basket } & Lapangan & 1 & $100 \%$ \\
\hline & & Tiang Ring & 2 & $100 \%$ \\
\hline & & Bola Basket & 12 & $100 \%$ \\
\hline & & Peluit & 4 & $100 \%$ \\
\hline \multirow[t]{4}{*}{3} & \multirow[t]{4}{*}{ Sepak Bola } & Lapangan & 0 & $0 \%$ \\
\hline & & Bola & 12 & $100 \%$ \\
\hline & & Tiang Gawang & 0 & $0 \%$ \\
\hline & & Peluit & 0 & $0 \%$ \\
\hline
\end{tabular}

Menjelaskan hasil bahwa sarana dan prasrana cabang permainan di SMP B (1) lapangan voli dengan secara rinci seperti tabel diatas mendapatkan 100\% masuk dalam kriteria Sangat Ideal. (2) Bola basket Bola voli dan bola sepak bola $55 \%$ kategori Cukup Ideal. (3) Peluit, lapangan sepak bola, gawang memilki persentasi 0\% kategori Kurang Ideal.

Tabel 4 Sarana dan Prasarana Kesehatan SMP B

\begin{tabular}{rlll}
\hline No & Sarana dan Prasarana & Jumlah & Persentase \\
\hline $\mathbf{1}$ & Ruang UKS & 1 & $100 \%$ \\
\hline $\mathbf{2}$ & Dipan Pemeriksaan & 2 & $100 \%$ \\
\hline $\mathbf{3}$ & Lemari/kotak obat & 1 & $100 \%$ \\
\hline $\mathbf{4}$ & Timbangan & 1 & $100 \%$ \\
\hline $\mathbf{5}$ & Pengukur tinggi badan & 1 & $100 \%$ \\
\hline $\mathbf{6}$ & Tensimeter & 1 & $100 \%$ \\
\hline $\mathbf{7}$ & Termometer & 2 & $100 \%$ \\
\hline $\mathbf{8}$ & Tempat sampah & 1 & $100 \%$ \\
\hline $\mathbf{9}$ & Alat P3K(obat-obatan) & 1 set & $100 \%$ \\
\hline $\mathbf{1 0}$ & Tandu & 2 & $100 \%$ \\
\hline
\end{tabular}

Dalam tabel diata mejelaskan bahawa fasilitas yang dimilki oleh SMP B kategori Sangat Ideal dibuktikan dengan persentase $100 \%$ alat yang ada. 
3. Kondisi sarana dan prasarana Pembelajaran dan Ruang UKS SMP C

Tabel 5. Sarana dan Prasarana Pembelajaran Pendidikan Jasmani, Olahraga, Dan Kesehatan Cabang Permainan SMP C

\begin{tabular}{|c|c|c|c|c|}
\hline No & Cabang & $\begin{array}{l}\text { Sarana dan } \\
\text { Prasarana }\end{array}$ & Jumlah & Persentase \\
\hline \multirow[t]{5}{*}{1} & \multirow[t]{5}{*}{ Bola Voli } & Lapangan & 0 & $0 \%$ \\
\hline & & Tiang & 2 & $100 \%$ \\
\hline & & Net & 3 & $100 \%$ \\
\hline & & Bola & 8 & $73 \%$ \\
\hline & & Peluit & 0 & $0 \%$ \\
\hline \multirow[t]{4}{*}{2} & \multirow[t]{4}{*}{ Bola Basket } & Lapangan & 0 & $0 \%$ \\
\hline & & Tiang Ring & 2 & $100 \%$ \\
\hline & & Bola Basket & 1 & $90 \%$ \\
\hline & & Peluit & 2 & $100 \%$ \\
\hline \multirow[t]{4}{*}{3} & \multirow[t]{4}{*}{ Sepak Bola } & Lapangan & 0 & $0 \%$ \\
\hline & & Bola & 8 & $73 \%$ \\
\hline & & Tiang Gawang & 0 & $0 \%$ \\
\hline & & Peluit & 0 & $0 \%$ \\
\hline
\end{tabular}

Menjelaskan hasil bahwa sarana dan prasarana cabang permainan di SMP C. Tiang net, net, tiang ring, peluit basket memiliki Persentase 100\% atau dalam kategori sangat ideal. 2) Bola untuk bola voli dan bola untuk sepakbola memiliki Persentase 73\% atau dalam kategori ideal. 3) Lapangan bola voli, peluit voli, lapangan bola basket, lapangan sepakbola, tiang gawang, dan peluit sepakbola memiliki Persentase $0 \%$ atau dalam kategori Sangat Kurang Ideal.

Tabel 6. Sarana dan Prasarana Kesehatan SMP C

\begin{tabular}{clll}
\hline No & Sarana dan Prasarana & Jumlah & Persentase \\
\hline $\mathbf{1}$ & Ruang UKS & 1 & $100 \%$ \\
\hline $\mathbf{2}$ & Dipan Pemeriksaan & 1 & $100 \%$ \\
\hline $\mathbf{3}$ & Lemari/kotak obat & 1 & $100 \%$ \\
\hline $\mathbf{4}$ & Timbangan & 0 & $0 \%$ \\
\hline $\mathbf{5}$ & Pengukur tinggi badan & 1 & $100 \%$ \\
\hline $\mathbf{6}$ & Tensimeter & 0 & $0 \%$ \\
\hline $\mathbf{7}$ & Termometer & 2 & $100 \%$ \\
\hline $\mathbf{8}$ & Tempat sampah & 1 & $0 \%$ \\
\hline $\mathbf{9}$ & Alat P3K (obat-obatan) & 1 set & $100 \%$ \\
\hline $\mathbf{1 0}$ & Tandu & 0 & $0 \%$ \\
\hline
\end{tabular}

Dalam tabel diata mejelaskan bahawa fasilitas yang dimilki oleh SMP C kategori sangat ideal dibuktikan dengan persentase $100 \%$ alat yang ada. Kecuali persentase pada imbangan, tensimeter, dan tandu bernilai $0 \%$

Hasil penelitian menumukan sebuah hasil penelitian sebagai berikut;

Tabel.7. Rincian Kondisi Sarana Dan Sarana Olahraga

\begin{tabular}{clll}
\hline No & Sekolah & Tahun & Persentase \\
\hline $\mathbf{1}$ & SMP A & 2019 & $64,34 \%$ \\
\hline $\mathbf{2}$ & SMP B & 2019 & $66,43 \%$ \\
\hline $\mathbf{3}$ & SMP C & 2019 & $42,66 \%$ \\
\hline \multicolumn{3}{c}{ Rerata Persentase } & $50,69 \%$ \\
\hline
\end{tabular}

Persentase penilaian kondisi sarana prasarana menemukan hasil bahwa SMP A tahun 2019 sebesar 64, $34 \%$, SMP B 66, 43\%, SMP C 42,66\%. Tabel menjelaskan serta kondisi yang ada dalam sarana dan prsarana 
yang ada Rerata Persentase menjalankan bahwa sarana dan prasarana untuk cabang permainan yakni sebesar $50,69 \%$ kategori Cukup Ideal.

Tabel 8. Rincian Kondisi Sarana Dan Prasarana Kesehatan

\begin{tabular}{rlll}
\hline No & Sekolah & Tahun & Persentase \\
\hline $\mathbf{1}$ & SMP A & 2019 & $100 \%$ \\
\hline $\mathbf{2}$ & SMP B & 2019 & $90 \%$ \\
\hline $\mathbf{3}$ & SMP C & 2019 & $90 \%$ \\
\hline \multicolumn{3}{r}{} & Rerata Persentase \\
\hline
\end{tabular}

Rerata Persentase sarana dan prasarana kesehatan di SMP di Kabupaten Pringsewu tahun 2019 sebesar $83 \%$ atau dalam kategori Sangat Ideal.

\section{PEMBAHASAN}

Prasarana dan sarana merupakan penunjang yang harus dimliki dalam aspek pembelajaran jasmani dan kesehatan. Walapun fungsinya hanya sebatas unsur penunjang apabila tidak adanya sarana prasarana yang baik proses belajar olahraga tidak akan berjalan secara optimal. Penyelenggara pendidikan sekolah membutuhkan fasilitas sekolah yang baik dan memenuhi kriteria yang memadai dengan begitu disebut ideal. Dalam aspek psikologis kondisi fasilitas sarana dan prasarana sekolah menunjang siswa dalam memberikan motivasi belajar yang baik sehingga ketercapaiannya proses belajar berjalan dengan efektif. Kurikulum nasional memiliki sebuah pencapaian dalam bidang olahraga untuk itu olahraga itu sendiri menjadi bagian yang sangat vital dalam mencapai kemampuan kognitif dalam aspek pendidikan tanpa mengadakan unsur afektif dan psikomotor. Melihat fasilitas yang ada di Kabupaten Pringsewu harus memliki fasilitas yang baik seperti prasarana kesehatan yang disebut dengan UKS sekolah yang sangat baik. Ketersediaan ruang belajar yang layak digunakan dalam proses pencapaian belajar mengajar guna pencapaian pembelajaran skala nasional. Berdasarkan penelitian yang dilakukan peneliti tahun 2019 masih banyak terdapat lapangan olahraga yang belum cukup layak digunakan , lapangan dijadikan multifungsi seperti kegiatan upacara bendera, olahraga serta kegiatan ekstrakurikuler yang ada disekolah. Keterbatasan tersebut banyak guru memakai fasilitas publik yang ada di pringsewu seperti alunalun dan lapangan yang dimilki lingkungan sekitar guna mencapainya proses kurikulum berjalan dengan baik. Peranan guru dalam memodifikasi dan memvariasikan alat dan media belajar menjadi suatu hal yang pokok dalam tercapainya proses belajar yang baik. Proses pembelajaran yag mengunakan lapangan dan media yang tidak bisa dimodifikasi guru harus lebih kreatif dengan memberikan edukasi terhadap pengenalan konsep dalam praktek lapangan serta hingga nantinya menggunakan alat yang sebenarnya dalam mendukung ketercapaian proses pembelajaran.

\section{SIMPULAN}

Penelitian memberikan sebuah keseimpulan bahawa prsarana dan sarana yang ada disekolah Kabupaten Pringsewu sebagai berikut. (1) Kondisi dalam cabang olahraga berbeda, seperti atletik, permainan dan aktivitas senam ritmik memiliki kriteria yang cukup ideal. (2). Guru di Kabupaten pringsewu sudah dapat memberikan inovasi dan memodifikasi sebuah alat belajar sebagai fasilitas belajar yang mengedepankan pencapaian kurikulum nasional. Alat modifikasi yang dibuat oleh guru bidang studi pendidikan jasmani dan olahraga cukup efektif mengatasi kekurangannya fasilitas sarana dan prasarna yang ada di setiap sekolah yang ada di kabupaten Pingsewu. Guru memodifikasi alat yang digunakan dalam cabang tertentu sepertui modifikasi prasarana seperti lapangan dengan ukuran yang lebih kecil, modifikasi peraturan yang kebih sederhana dan memodifikasi alat seperti alat pemukul raket, tiang lapangan, bola dengan ukuran yang bukan sebenarnya. Akan tetapi modifikasi tersebut berdampak positif dalam proses belajar yang menyebabkan anak menguasai secara baik model permainan dan dasar gerak kecabangan secara sempurna.

\section{DAFTAR PUSTAKA}

Abror, Hisyam. (1991). Fisiologi Pembelajaran dan Masa Depan Pendidikan Jasmani. Bandung: Yayasan Nuansa Cendekia

Arikunto, Suharsimi. (2012). Prosedur Penelitian Suatu Pendekatan Praktek. Jakarta: Rhineka Cipta

Suherman, Adang. (2003). Dasar-dasar Penjaskes. Jakarta: Direktorat Jenderal Pendidikan Dasar dan Menengah Bagian Proyek Penataan Guru SLTP Setara DIII. 
Gumantan, Mahfud. (2018). Perbandingan Latihan Menggunakan Bola Ukuran 4 dan 5 Terhadap Ketepatan Menendang Bola. Journal Of S.P.O.R.T.. 2 (1), 1-8

Mahfud, Gumantan. Fahrizqi (2020). Analisis Indeks Masa Tubuh Atlet Sepak Bola Universitas Teknokrat Indonesia. SATRIA Journal Of Sports Athleticism in Teaching and Recreation on Interdisciplinary Analysis. 3 (1), 9-13

Mahfud, Bagus. (2020). Pengembangan Model Latihan Keterampilan Motorik Melalui Olahraga Tradisional Untuk Siswa Sekolah Dasar. Sport Science \& Education Journal. 1 (1), 31-37

Soepartono. (2000). Sarana dan Prasarana pembelajaran Pendidikan Jasmani Olahraga dan Kesehatan Cabang. Departemen Pendidikan dan Kebudayaan.

Sutopo. (2002). Metodologi Penelitian Kualitatif: Dasar, Teori, dan Penerapannya dalam Penelitian. Surakarta: UNS Press.

Wirjosantoso, Ratal. (2005). Supervisi Olahraga Pendidikan. Jakarta: Universitas Indonesia

Yuliandra, Fahrizqi. (2018). Pengembangan Model Latihan Jump Shot Bola Basket. Journal Of S.P.O.R.T. 2 (1), 36-72

\section{BIOGRAFI PENULIS}

\begin{tabular}{|c|c|}
\hline & $\begin{array}{l}\text { Nur Afifah Sudibyo } \\
\text { lahir di Pringsewu, saat ini sedang menempuh Pendidikan Strata-1 di Universitas } \\
\text { Teknokrat Indonesia dengan mengambil Program Studi Pendidikan Olahraga } \\
\text { angkatan 2017. Aktif sebagai asisten dosen dan aktif sebagai pemain futsal wanita } \\
\begin{array}{l}\text { dan sepakbola. Penulis dapat dihubungi melalui Email : } \\
\text { nurafifahsudibyo1@gmail.com }\end{array}\end{array}$ \\
\hline & $\begin{array}{l}\text { Reza Adhi Nugroho, M. Pd } \\
\text { Setelah Menyelesaikan pendidikan Program Sarjana (Strata -1) pada Fakultas Ilmu } \\
\text { Keolahragaan dengan Program Studi Pendidikan Jasmani, Kesehatan dan rekreasi } \\
\text { tahun 2010-2014 di Universitas Negeri Yogyakarta, dan melanjutkan Program } \\
\text { Pascasarjana Magister Pendidikan (Strata-2) pada Program Pasca Sarjana Universitas } \\
\text { Negeri Yogyakarta dengan mengambil Program Studi Pendidikan Olahraga dan } \\
\text { selesai tahun 2017. Aktif sebagai anggota organisasi bolabasket di Perbasi } \\
\text { Pringsewu. Penulis juga sebagai pengajar pada Universitas Teknokrat Indonesia pada } \\
\text { Program Studi Pendidikan Olahraga (2019-Sekarang). Penulis dapat dihubungi } \\
\text { melalui email: reza.adhi.nugroho@teknokrat.ac.id }\end{array}$ \\
\hline
\end{tabular}

